\title{
Earthen Stūpas of Pre-ancient Nepāl
}

\author{
Junu Basukala Ranjitkar PhD."
}

\begin{abstract}
The initial stüpas of pre-ancient Nepal were erected using earthen mounds. However, the Pāli and Sanskrit Buddhist texts do not mention that stüpas have to be earthen mounds. Only the Pāli Jātaka story Sujāta mentions the presence of earthen mound stupa containing the relics of a deceased person. The earthen mound stüpas were initially made in the Indian sub-continent after Buddha's Mahāparinibbāna. There were ten preliminary stüpas that were erected containing the Buddha's relics, a vessel and ashes. One of them, Rāmagrāma stüpa, is still in existence in its original form. When Emperor Asoka converted to Buddhism, he erected 84,000 stüpas with small relics of the Buddha, extracting those relics from the seven original stüpas. Not only that, he also went on to enlarge the size of a few original stūpas using bricks in the construction process. Piprahavā stūpa of Kapilvastu, Nibbāna stūpas of Kanakamuni and Krakuchhanda, twin stüpas of Dhamnihavā were renovated by enclosing the earthen mound with bricks. The Bhishvā stüpa of Birgunj and three stūpas of Pātan and a stüpa of kothuvahi are still in existence in their original form. However, all these stupas are enclosed by walls built in the later part of the centuries to preserve them. The Chārumatī stūpa and the Yampi stūpa were built in Vajrayāna tradition. However, in recent times the infrastructure developments in the cities have led to the use of modern materials like cement and white plaster and altering even the architectural styles of some of the stupas. The north-east section of Chärumatī stūpa and the Yampi stüpa have suffered this impact.
\end{abstract}

Keywords: Rāmagrāma stūpa, Piparhavā stupa, Chārumatī stūpa, Four stūpas of Pātan, Bhishvā stūpa, Dhamnihavā stupa.

\section{Introduction}

The stūpas are the oldest religious monuments of Nepāl and numerous stūpas of archeological and historical values still exist in different parts of the country. There are different styles of stūpa architecture, and they are constructed using various materials such as earthen mounds, bricks, stones, and metals. In pre-ancient time (up till 3rd CE) stūpas were built using two materials: earthen mound and bricks. The original and initial Rāmagrāma stūpa

\footnotetext{
* Lecturer Patan Samyukta Campus, T.U., Patandhoka
} 
at Rāmagrāma was erected right after the Buddha's Mahāparinibbāna. In Kapilvastu, there are stūpas that were raised during the pre-Ashokan and the Ashokan period in the 3rd century BC. The four stūpas of Lalitpur and Kothu Bahī of Kathmandu are assumed to have been made also around the 3rd century BC. Likewise, the Bhishvā stūpa of Birgunj also possess features of the initial stupa but the date of its construction have not been identified.

\section{Problems of the Study}

The initial stūpas were erected using earthen mounds or a heap of clay in the Indian subcontinent tradition. Such kinds of earthen stūpas were also erected during the pre-ancient times of Nepāl. Although some of them are still in existence they have been modified over time. It is difficult to say when and who commissioned the making of those stūpas as there is no significant scientific evidence to support their claimed history. The Archeology Department of Nepāl has not examined these earthen stūpas using radiocarbon process yet. Furthermore, no official counting has ever been done to document the existing earthen stūpas in Nepāl. In this regard, this paper aims to study the archeologically documented and existing earthen stūpas and how they have been modified from their preliminary structure.

\section{Objectives of the study}

This paper presents a few studies of earthen stūpas of Nepāl from the pre-ancient period which are currently in existence. The general objective of this study is to chronicle the earthen stūpas of Rāmagrāma, Kapilvastu, Birgunj, and Kathmandu Valley through field and cultural observation and published documents. The specific objectives are:

- To find and establish evidence to show or approximate when those earthen stūpas were erected.

- To provide insight on when and how those stūpas were modified and their current situation.

- To find information on the reasons for the modification of those stūpas.

\section{Methodology}

This article is based on a descriptive, qualitative, archaeological and historical research design. This research work is written based on collective information from two prime sources i.e. primary and secondary sources. The primary sources include the information gathered from observation, archaeological research documents, brick and stone inscriptions. The secondary sources incorporate information from research documents of various books, journals, and published articles. 


\section{Background}

As per the record in the Mahāparinibbāna sūtta, there were raised ten stūpas after his Mahāparinibbāna at four cross-roads. ${ }^{1}$ Accordingly, these stūpas were raised with eight stūpas containing the relics of the Buddha, one containing a vessel, and one above containing the ashes of the Buddha. ${ }^{2}$ However, there is no information available that describes the building material of these stūpas. Based on the existing tradition in the Indian subcontinent of building earthen mound stūpas, it can be assumed that those ten memorial stūpas of the Buddha could have been simply made from the earthen mounds. One of the ten initial stūpa is still in existence at Rāmagrāma stupa made by the Koliyas. Sujāta Jātaka tells that after the death of Sujāta Kumār's grandfather, Sujāta's father built an earthen stūpa at his own garden and kept some relics of Sujāta's grandfather inside it. ${ }^{3}$ It indicates that stūpas of those periods were likely raised from the earthen mound containing relics or ashes of the deceased person.

It is said that when King Aśoka converted to Buddhism after the Kalinga war (3rd century BCE), he developed stūpa architecture as an object of cult worship. He opened the seven original stūpas, ${ }^{4}$ redistributed relics, and erected 84,000 stūpas all over Jambudvipa. According to the legend, when he proceeded to open the Rāmagrāma stūpa, the king encountered a Nāga who guarded the stūpa round the clock and worshipped it every day. King Aśoka requested the Nāga to allow him to break the stūpa with the commitment of rendering better services to the stūpa than that offered by the Nāga. However, after many unsuccessful attempts the king thought it was impossible to convince the Nāga and thus dropped the idea of breaking the Rāmagrāma stūpa. ${ }^{5}$ Incidentally, it is the only initial

1. Bhikkhu Pesala, 'An Exposition of The Mahāparinibbāna Sutta, pdf.' Google. Oct. 2018. Access on $30^{\text {th }}$ Nov. 2020. http://www.aimwell.org/An\%20Exposition\%20of\%20the\%20Mahaparinibbana\%20Sutta. pdf

2. King Ajātasatru of Magadha, the Licchavis of Vaisālī, the Sākyas of Kapilavastu, the Bulas of Allakappa, the Koiyas of Rāmagrāma, the Brāhman of Vethadīpa, the Mallas of Pāvā, the Mallas of Kusinagara, the Brāhman Droa, and the Mauryas of Pippalivana were eight monuments for the relics, a ninth for the vessel, and a tenth for the ashes respectively.

3. Jataka 352

(Trans. Dunda Bahadur Vajracharya). Jataka. Lalitpur: Bir-Purna Pustak Samgrahalaya. 2011, pp. 109110 Print.

4. Rājagriha, Vaisāli, Kapilavastu, Allakappa, Vethadipa, Pāvā and Kusinagara

5. Mahāvamsa states that the stūpa of Rāmagrāma stood on the bank of a river and was destroyed by the action of the current, and the relic casket was flown down to the ocean. It was discovered by the Baga and was enshrined inside a stūpa. It was the reign of Dutthagāmini that the relic casket of Rāmagrāma stūpa was miraculously obtained by the monk Souttaro and put inside the Mahāthupo in Si Lanka. 
earthen mound stūpa currently in existence. It is an enormous mound with a height of more than 30 feet and a diameter of around 70 feet. ${ }^{6}$ Hiuen Tsiang, in his travel accounts also mentions the height of this stūpa as 30 feet. $^{7}$ Thus, it is speculated that the other nine initial stūpas of Buddha were also erected using earthen mounds with the relics, a vessel and ashes after Buddha's Mahāparinibbāna.

\section{Piparhavā Stūpa (after Buddha's Mahāparinibbāna)}

The Piparhavā stūpa is one of the structures made after Buddha's Mahāparinibbāna. It was built by the Sākyas of Kapilvastu. Twenty years after its construction, it is thought that Bhikshu Mahā Kāsyapa, the chief of the Vihāra, took away some of the relics either from this stupa or from another one and buried them in an underground structure at Rājgir. ${ }^{8}$ Vincent Smith mentions, "the stūpa of Piprahavā might be the relics of Buddha, which was raised by Śākyas right after Buddha's Mahāparinibbāna. The stūpa of Piprahavā may well be unlikely that the inscription is later than B.C. 400, and it is quite possible that it may be earlier." ${ }^{\prime}$ But when W. Peppe excavated the mound at Piprahavā, he discovered a large stone-box inside the rectangular chamber, in which there were five caskets; four of soapstone and one of crystal containing bones, gold stars, and beads of sorts as also some figures. etc. in the core of the stūpa. There was also an inscription of 'the sarīras of the Buddha'. ${ }^{10}$ This proves that the mound was enshrined by the Sākyas.

\section{Earthen mound of Kapilvastu (since Buddha's Mahāparinibbāna till Aśokan period)}

Kapilvastu is one of the most important sites in tracing these initial stupas. It is assumed that there are numerous stupas spread in the region. Many of them are thought to be buried underground and require excavation. One of the most prominent structures that narrates the rich past of Kapilvastu is the inscription found on the Niglihavā pillar. It states that Emperor Aśoka doubled the size of the stūpa of Kanakmuni Buddha. ${ }^{11}$ According to P.C. Mukherji

6 Vincent Smith. 'Introduction to Devadaha'. 100 years of Archaeological Research in Lumbini, Kapilvastu \& Devadaha. Kathmandu: S.K. International Publishing House. 1996. p. 50. Print.

7 Samuel Beal. Si-yu-ki Buddhist Records of the Western World. Vol. II. Delhi: Low Price Publications. 2008. P. 78. Print.

8 Babu Krishna Rijal. 'Archaeological Note on the Twin Stūpas in Dhamnihawa, pp. 119-125'. Nepālese Cultural Heritage in a Nutshell. Kathmandu: H.M.G. Hotel Management \& Tourism Training Centre. No Date. P. 13. Print.

9 Vincent A. Smith. 'Prefatory Note, pp. 1-22'. Antiquities of Kapilvastu Tarai of Nepāl. Varansi: S.B. Singh. 1901. p. 17. Print.

10 Babu Krishna Rijal. 100 years of Archaeological Research in Lumbini, Kapilvastu \& Devadaha. Kathmandu: S.K. International Publishing House. 1996. p. 85. Print.

11 Devanam piyena piyadasin lajina-chodasavasa bhisitena Buddhasa Konnakamansa thube-dutyam vadhite 
about his exploration of Nepāl's Terai, “The great Nirvāna stūpa of Konāgamana, is despite its great age still fairy well-preserved and rears its imposing pile close to Aśoka's Edict Pillar, just one mile and a half due north-east of Tilaurakot and about one-mile south of the village of Niglihavā. Amongst the heaps of ruins, the Nirvāna stūpa of Konāgamana is clearly discernible, the base of its hemispherical dome being about 101 feet in diameter, and its present height still about thirty feet. The dome seems to have been constructed of solid brick to a depth of about 20 feet, whilst the interior is filled up with earth-packing. ${ }^{12}$ This statement indicates that the initial material used to erect the Nibbāna stūpa of Kanakamuni Buddha was earthen mound. The report also mentions that this stūpa rests on a great circular mass with 109 feet in diameter, and was built in the shape of a huge brick drum, about six feet high, cased with solid bricks. Emperor Aśoka might have covered the earthen mound with bricks to preserve the stūpa from flood or perhaps it was a requirement of stūpa architecture of that time. Based on these facts, this stupa is likely one of the oldest earthen stūpa of Nepāl but unfortunately in present times there is no knowledge of its whereabouts. However, the stupas of Bharhut, Sãnci and Bodhgayā whose initial earthen mounds were enclosed by bricks during the Ashokan period still exist. ${ }^{13}$ Along with the lost stūpa of Niglihavā, they are part of the 84,000 stūpas and new structures that emperor Aśoka commissioned to be built using the brick and earthen mound technique.

The Chinese travelers Fah-hian (5th century CE) and Hiuen Tsiang ( 7 th century CE) mention in their travels accounts that they sighted many stūpas at different sites in their journey of the Indian subcontinent. Fah-hian reports that he saw a stūpa where Asita Rishi calculated the horoscope of Prince Siddhārtha. ${ }^{14}$ Both of them describe seeing stupas of Gotihavā, where Krakuchanda Buddha was born, met his father and attained Nibbāna. ${ }^{15}$ They saw stūpas at Niglihavā, where Kanakamuni Buddha was born, completed enlightenment, met his father and attained Nibbāna. ${ }^{16}$ Also, they saw another stūpa that was made to fall under the shade of a legendary tree. ${ }^{17}$ They further record seeing hundreds and thousands

Basanta Bidari. Kapilvastu The World of Siddhartha, Lumbini: The Sacred Garden. 2007. p. 87. Print.

12 Vincent Smith. 'Introdution to Devadaha'. 100 years of Archaerological Research in Lumbini, Kapilvastu \& Devadaha. Kathmandu: S.K. International Publishing House. 1996. p. 3. Print.

13 H. Sarkar. Studies in Early Buddhist Architecture of India. Delhi: Munshiram Monoharlal. 1966. p. 4.

Print.

14 Ibid. p. 86.

15 Samuel Beal. Travels of Fah-hian and Sung-yu AD 400 and 518 Buddhist Pilgrims from China to India,

New Delhi: Asian Educational Services. 1869. P. 84. \& Beal, op. cit.no. 7. pp. 18-19.

16 Ibid. \& Beal, op. cit.no. 7. P. 19.

17 Ibid. p. 87 \& Ibid. P. 19.

The event goes that when prince Siddhārtha was a six-month old baby his nurses kept him under its shade 
of stūpas dedicated to the members of the Sākyas tribes who were brutally slaughtered by Viddubha during the time of Buddha. Hiuen Tsiang notes that along the south-western flanks of the place of massacre, there existed four little stūpas where four Sākya warriors withstood the invading army. ${ }^{18}$ Another stūpa existed at the eastern gate of the city where prince Siddhartha purchased arts. Hiuen Tsiang further writes, "From this spot, 30 li southeast is a small stūpa, which is a fountain, the waters of which are as clear as a mirror." He saw another landmark stūpa that was made at the site where prince Siddhārtha terminated his charioteer Chandaka and the horse Kanthaka, before bidding goodbye to them as they returned to the palace. ${ }^{19}$

Both of these early travelers seem to have witnessed many such important stupas. The list goes on. There was a stūpa near the grove of Nyagrodha tree where King Suddodhana met his son, the Buddha. Beside the Nyagrodha vihāra, there was a stūpa where Buddha sat beneath a great tree and received Samghāti from Prajāpati Gautami while facing the eastern direction. A little further on, there was another stūpa, where the sons of the eight kings and five hundred Sa âkyas converted to Bhikshus. ${ }^{20}$ Interestingly, although they have chronicled the details of their sighting of these important stupas none of them mention the building material used in these stūpas. Furthermore, there are no significant documents available on who raised these stūpas and when. These stūpas might have been erected before Aśoka's reign and during his reign he probably renovated them using bricks over their earthen shapes.

The Nepālese and Italian joint archaeological team explored east of the Bānganga River, west of the Kothi river, south of the east-west highway and north of the Indian Border in Kapilvastu during 1996 to 1997 . They excavated nine archaeological sites located in and around Niglihavā highway. They discovered four prominent mounds full of ancient pottery and brickbats along the north-east section of Taulihavā up to Jitpur road before it meets the east-west highway. To the south west of this road, there are four archeological sites that are identified. Furthermore, there are nine more sites identified in and around Niglihavā: Thumwa, Semari, Thagi Baba Ki Dadi, Araurakot, Derwa, Gobari, Shivapura, Banduli and Niglihavā. According to the local people, beads, terracotta figurines, coins and other objects found in this region during the rainy season. Tumwa, the archaeological site closest to the

and went to watch a summer ploughing festival. When they returned to their surprise they found that the sun had moved but the shadow on the baby Siddhartha remained still.

18 Beal, op. cit. no. 7. P. 20.

19 Ibid. pp. 86-87.

20 Ibid. P. 22. \& Beal. Op. cit. no. 14. P. 87. 
Niglihavā pillar, could be one of the mounds that might have been the ancient stūpa seen and mentioned by the two Chinese travelers. ${ }^{21}$ It shows that there were many earthen stuppas during the pre-ancient time. There is a possibility that many such earthen stūpas were lost and damaged due to the natural disaster.

Initially, Fuhrer had found three stūpas at Kudān in 1985 which were also mentioned by Fah-hian and Hiuen Tsiang. ${ }^{22}$ In 1899, P.C. Mukherji visited this location and he describes seeing four ancient mounds from north to south. According to his account, the northernmost figure appears to be a stūpa of solid bricks still about 80 feet high. ${ }^{23}$ Those structures might have been the initial stūpas built from earth mound and later enclosed by bricks during Emperor Aśoka's time. However, in the later centuries the bricks were removed by villagers to raise a modern temple. ${ }^{24}$

P.C. Mukherji also explored Gotihavā in 1899. In his report he writes, "At the center of the villages, there is a large brick stūpa, which is 68 feet in diameter and 9 feet high., ${ }^{25} \mathrm{He}$ also states that "North-west of this stūpa, I could not find another. But about two furlongs north-east of the village is a very high mound, which might represent either the stūpa of Krakuchhanda's meeting with his father, or the place where he was born". ${ }^{26}$ Devalā Mitra states that the lower portion of the base of the Krakuchhanda stūpa is still in its original shape. The stūpa was already in a development of the earlier mound set up on the ground. ${ }^{27}$ The brick stūpa arising near the Aśoka pillar has been fully exposed, revealing a diameter of $22 \mathrm{~m}$, not including the circumambulatory path. Two building phases have been noticed, the first corresponding to the original structure, which goes back at least to the time of Aśoka, and the second to a later enlargement or rather, a restoration and strengthening of the old structure, which can be dated to the first or secondary century CE. ${ }^{28}$

At a distance of about 500 yards north of the royal quarter of Kapilvastu, there is a small site on the eastern bank of Bāngangā river, which is known as Dhamnihavā. There are twins' stūpas $52 \mathrm{ft}$ and $26 \mathrm{ft}$. diameter respectively. However, the local believes that the larger stūpa is dedicated to king Suddhodana and the smaller one, which is situated towards

21 Basanta Bidari. Kapilvastu The World of Siddhartha. Lumbini: The Sacred Garden. 2007. p. 102. Print.

22 Ibid. 9.

23 Ibid. 10.

24 Ibid. 10.

25 Ibid. 54-55.

26 Ibid. 56-57.

27 Ibid. 60.

28 Ibid. 66. 
the left of the bigger stūpas is attributed to the Queen Māyā Devī. The stūpas that were built to commemorate the auspicious parents of the Buddha may mark an important spot in Buddhist archaeology. ${ }^{29}$ Babu Krishna Rijal, mentions that the big stūpa is likely to have been built in commemoration of Suddhodana, during N.B.P. period. Its core contained a mud stūpa of size $47^{\prime} 8$ " in diameter. The available height is 3 feet. The base of the mud stūpa was prepared by digging the peripheral trench of the depth of 2' 5" and by piling up the rammed yellowish clay mixed with kankar. ${ }^{30} \mathrm{He}$ also mentioned that "In the second phase of construction, the mud stūpa was veneered by tapered bricks of size 17 " $\times 9$ " -12 " $\times 3$ ". The technique applied by veneering at the lowest base was by exposing $1 / 2$ " thickness of the set bricks above the ground. During the period of the first brick encasing, the basal diameter of the stūpa was enlarged from 47' $8^{\prime \prime}$ to 52 feet. The frontal face all around the stūpa was vertically raised to 4'6" above the ground and then concentric circles of the tapered bricks were provided up to the height 7 ' 7 " towards top. The smaller stūpa has suffered a greater damage, and at present remains covered up with earth enclosed within a 5 feet high circular retaining wall that was built during the conservation of this site in 1972-73 A.D. The ancient bricks employed in the surface of the smaller stūpa are of three types, viz $161 / 2$ " $\times 12$ " and $9 " \times 3 \frac{1 / 4}{4}$ in the middle courses and $17 " \times 13$ " and $11 " \times 3 \frac{1 / 2}{2}$ in the lower course." ${ }^{31}$ Babu Krishna Rijal, assumes that the twin stūpa built very close to the 1st course_of the Bānganga, the heavy flood of the river battered them from time to time. Around 1st Century B.C., when the larger stūpa was badly disintegrated by the seepage of water, a revetment wall with maximum height of 4' 5" was constructed towards the southern face. Most of the bricks for the construction of the revetment wall was quarried from the fallen debris of the twin stūpa. ${ }^{32}$ It also proves that the twin stūpa of Dhamnihavā was raised by using an earthen mound in the preliminary stage. However, we cannot claim that the twin stūpas were erected during Buddha's time and later. There is no significant evidence to prove it either.

\section{Bhishvā Stūpa}

There is an earthen mound or Bhishvā stūpa in Birgunj of Parsā district. People believe that this stūpa might have been erected more than two thousand years ago. Bhikshu Vagindra Vajra Vajracharya termed the site as a stūpa for the first time around four decades ago. It is said that the Rana rulers (1850-1954 CE), assuming that a trove of treasure and jewelry were

29 Rijal. op. Cit. No. 8. P. 119.

30 Ibid. p. 120.

31 Ibid.

32 Ibid. 120-121. 
hidden inside the stupa, excavated the site but instead found only the ancient bricks and ashes. After seeing it, they stopped excavating and considered it as a Buddhist monument. Purna Harsha Bajracharya, sculptor expert of the Archaeology Department of Nepāl declared the site as a Buddhist site in 2034 V.S. (1977) and recognized it as the Bhishvā stūpa. Since then, Buddhists of Nepal and all over the world have made pilgrimage to this Buddhist monument. On the Baisākha Purnimā in 2035 V.S., Mahāyāna Bhikhus of Hetaudā and Vajrayāna Priest Badri Ratna Bajracharya, worshipped jivanyāsapūjā (consecration) on the stūpa as per Mahāyāna and Vajrayāna tradition respectively. After these events, several Hindu and Buddhist deities were installed over the stūpa. ${ }^{33}$ Mahāparnibbāna Sūtta mentions that the Mauryas of Piplivana had erected the stūpa with Buddha's ashes after Buddha's Mahāparinibbāna. ${ }^{34}$ However, the precise location of Piplivana is not mentioned in any of the Pāli and Sanskrit Buddhist texts, documents or any archaeological objects. The Bhishvā stūpa of Bīrgunj was located on Vrijji Janapada during Buddha's time. We cannot firmly state that this stūpa was erected after Buddha's Mahāparinibbāna due to lack of scientific evidence. The Archaeology Department of Nepal has not examined this area too using radiocarbon yet. On the contrary, the department without any proper investigation, has declared this stūpa as being built during the Licchavi period instead.

\section{Pre-ancient Earthen Stūpas of Kathmandu Valley}

Chārumatī stūpa seems to have been erected in the 3rd century $\mathrm{BC}$, based on legends, chronicles and two archaeological objects. The chronicle of the History of Nepal ${ }^{35}$ mentions that Chārumatī was the daughter of Emperor Aśoka. ${ }^{36}$ The local Buddhist people also believed that Chārumatī was Aśoka's daughter and she commissioned the construction of this stūpa. During the renovation of the stūpa in $2002 \mathrm{CE}$, two peculiar bricks were discovered. The first brick has a size of $35.5 \mathrm{~cm} \times 23 \mathrm{~cm} \times 7 \mathrm{~cm}$ and is embedded with a wheel and the letters "ca ru va ti thu pa" in Brāhmi script. The second brick is $34 \mathrm{~cm} \times 21.5 \mathrm{~cm} \times 7.5 \mathrm{~cm}$ in size, and is engraved with a wheel, two svastikas, and the words "ca ru va ti" in Brāhmi script and "caruvati dhande hetu prabha" in Bhujimol script. ${ }^{37}$ Both of them are currently kept at the National Museum in Chāuni, where the first brick is displayed in the Buddhist

33 Junu Basukala Ranjitkar. 'Mahotsavama matrai Chamkiyeko Birgunjsthita Visva Stūpa', Sampada Nepāl, year II. no. 2, 2068 V.S. pp. 44-45. Print.

34 Op. cit. no. 2.

35 A chronicle is written on the $19^{\text {th }}$ century edited by Daniel Wright and it is known as History of Nepāl.

36 Daniel Wright. History of Nepāl. $3^{\text {rd }}$ Edition. Calcutta: Ranjana Gupta. 1966. p. 74. Print.

37 Ranjitkara, Junu Basukala. Tehis Saya Varsa Purano Eitihasika Carumati Stūpa. Kathmāndu: Chārumatī Buddhist Misson Nepāl. 2011. P. 30. Print. 
Section whereas the second brick is kept in the store. National and international scholars disagree with the relation between Chārumatī and Aśoka based on the history of Nepāl, chronicles and legends because other documents of Nepal and India do not mention anything regarding Chārumatī as the daughter of King Aśoka. Furthermore, even the findings from the renovation of the stūpa in $2002 \mathrm{CE}$ could not provide any such evidence. ${ }^{38}$ However, it is interesting to note that the History of Nepal does state that King Dharmadatta erected the stupa in the north-west corner of Paśupati temple. ${ }^{39}$ The chronicle also mentions that Dharmadeva, son of Sankardeva, seems to have renovated a stūpa in the north-west corner of Paśupati temple. ${ }^{40}$ According to Silvain Levi, King Vrishadeva renovated a stūpa in the north-west side of Paśupati temple. ${ }^{41}$ The three versions clearly indicate that Dharmadatta raised a stūpa in the north-west of Paśupati Temple, which could be the Chārumatī stūpa since it is located exactly at the north-west side of the Paśupati Temple. Dipavamsa and Mahāvamsa mention that Emperor Aśoka had sent Buddhist commissionaires to nine countries. Among them, Majjhim Thera was selected travel in the Himalayan region. ${ }^{42}$ Since Kathmandu Valley was known as the Himālayana region, it is likely Chārumatī also joined Majjhima Thera and came to Kathmandu. The legend and chronicle indicate that Chārumatī stūpa was raised in the 3rd century BC and is one of the earliest stuppas of the Kathmandu Valley. The stūpa is related with Chārumatī, a fact which is now proved through the discovery of the two bricks. Although Chārumatī did not have any sort of authentic connection with Emperor Aśoka, Chārumatī is considered as a historical personality of the 3rd century BC in Nepal. In India and Sri Lanka, the Buddhist documents chronicle the names of queens, sons and daughters of king Asoka but those documents do not mention the name Chārumatī as Asoka's daughter. It can be speculated that perhaps Chārumatī might have been the daughter of Asoka born from an illegitimate wife therefore her name may not have been included in the family tree. Many Aśoka pillars in Nepāl and India possess Brāhmi script and Pāli language; a dhamma wheel is inscribed in some Buddhist monuments such as the ones in Sārnāth and Sãnci made by Emperor Aśoka. Incidentally, similar patterns of Brāhmi script, Pāli language and a dhamma wheel is inscribed in both the two bricks recovered from the Chārumatī stūpa renovation in 2002. Therefore, it is

38 Junu Basukala Ranjitkara. 'Essence of Recognizing Charumati Stūpa as World Buddhist Heritage'.

International Buddhist Conference on "Promotion, Protection \& Preservation of Buddhist Culture and

Heritage". 15-18 Nov. 2014. Print.

39 Wright. op. cit. no. 36, p. 61.

40 Ibid. p. 83.

41 Silvain Levi (Trans. Dilli Raj Upreti). Nepāl. Part II. Lalitpur: Hiaml Kitab. p. 67. Print.

42 Madhukara Pipllayana. Mahan Samrat Asoka. $5^{\text {th }}$ Edition. Nai Delhi: Samyaka Prakashana. 2008. p. 56.

Print. 
likely that somebody elevated this stūpa and inscribed "ca ru va ti thu pa" and the wheel after her nivvāna. In this manner, among the four types of stūpa, ${ }^{43}$ Chārumatī stūpa could be the Sarirīka stūpa or Dhamma stūpa. ${ }^{44}$ Mahāparinibbāna sūtta mentions that according to Buddha, stūpas could be raised based on four different personalities. ${ }^{45}$ The chronicle History of Nepal also states that Chārumatī built a vihāra and stayed there till her death. ${ }^{46}$ Chārumatī could became arhant and Chārumatī stūpa was erected after her Nivvāna. So it is difficult to assume to whom did the relics discovered during the 2002 renovation belong to - Buddha or Chārumatī or any other person. One of the missionaries of Aśoka might have erected this stūpa with the relic. With this logic, this stūpa might be one of the 84,000 stūpas of Aśoka. The chronicle also states that Chārumatī built a vihāra. According to the Buddhist tradition, a stūpa must be installed within the vihāra for worshipping. The stūpa built for worshipping is known as Dhamma stūpa so it is likely that Chārumatī wished to raise a Dhamma stūpa. Although this stūpa is Sārirīka or Dhamma stūpa, the preliminary stūpa could have been erected using an earthen mound. The chronicle also states that the stūpa was renovated by the Lichchavi kings. Through time, the Chārumatī stūpa has been modified with more complex and new additions. According to the different inscriptions, which are installed surrounding of the Chārumatī stūpa shows that from 7 th century till 2002, there is a record of constant renovation taking place at Chārumatī stūpa once every 140 to 160 years, except once in the 9th century. It is evident that these renovations added new elements to the structure.

Currently, the Chārumatī stūpa stands in the Vajrayāna tradition form on a circular ground plan, the mandal. It is a 158 feet long by 158 feet wide semi-circle white plastered dome sitting on top of the vedika (plinth). It contains inscriptions and caityas while different images are imprinted at the base of the dome. The images of four Buddhas: Akshobhya, Ratnasambhava, Amitābha and Amoghsiddhi are installed on the stupa facing the east, south, west and north respectively with three roofed temples. Vairochona Buddha is symbolized at the south-east corner of the dome. A cubic shape of harmika is placed above the dome and the images of Vajradristi, Urnā and Kunjik $\bar{a}$ are depicted on all four sides. The square-

43 Saririka stupa, paribhoga stupa, dhamma stupa and udesika stupa.

44 Ranjitkara. op. cit no. 37. pp. 12-17.

45 Dighanikaya, verse 207

"Cattārome, Ānanda, thūpārahā. Katame cattāro? Tathāgato araha $\square$ sammāsambuddho thūpāraho, paccekasambuddho thūpāraho, Tathāgatassa sāvako thūpāraho, rājā cakkavattī thūpārahoti."

Op.cit. no. 1.

46 Wright. op. cit. no. 36. P. 74 
shaped thirteen tiers get narrower starting from harmikā to ushnisha and the jewel. The four dandas, chatra and pinnacle are placed above the stūpa.

In the north-east corner of Chārumatī stūpa, another earthen stūpa existed before the construction of the ring road, around 45 years ago. The local people worshipped and circumambulated it daily. According to the local people, this earthen stūpa was smaller than Pulchok and Lagankhel stūpas of Pātan. When it was destroyed during the construction of the ring road, some metal, clay and skin coins were discovered. Later on, this earthen mound was rebuilt in a modern style, which was erected within the compound of Chārumatī stūpa in the north-east corner. ${ }^{47}$

There are still earthen mound stūpas in Pātan. The chronicle History of Nepal states that when Emperor Aśoka visited Nepāl, he established four stūpas on the auspicious day of the commencement of one of the yugas. ${ }^{48}$ David Snellgrove has argued that the four stuppas might have been erected in connection with the foundation of Pătan towards the end of the 4th century AD. ${ }^{49}$ The local Buddhists believed that Emperor Aśoka had once visited the Valley and established five such stūpas in Pātan. They say four stūpas were erected in four directions while the fifth one was established in the centre. The four stūpas are still in existence in four directions in the Valley. They are known as Tetā thura in the east, Lagan thura in the south, Phucho thura in the west and Yampi thura in the north by local people of Kathmandu Valley. Marry Slusser opines that "There is no evidence that the Kathmandu Valley was part of the Maurya Empire of India or, despite the widespread belief to the contrary, that Asoka, its ruler from about 269 to $232 \mathrm{BC}$, visited it. The ample Indian and Ceylonese sources concerning the Maurya ruler are silent about Nepal or a Himalaya visit. It is also quite possible that the four stūpas of Patan are in fact pre-Mauryan and Pre-Buddhist cult objects." ${ }^{50}$ She also says that "There is possibility that there was also a fifth mound closely related in form and size to the well-known four which if identified at all is frequently considered to be the stūpa at Pimbāhal. Although it is true that the latter represents a restoration almost a decade after its destruction by Shams-ud-din, the stupa corresponds in neither size nor type to the other mounds, and rather than at the center of the city, it lies almost at its western limit. If there were a fifth stūpa, there is a strong possibility that it is the unexplored midden just northwest of the Durbar Square, today

47 Ranjitkara. op. cit no. 37. p. 43.

48 Wright. op. cit. no. 36. p. 77.

49 Niels Gutschow. The Nepālese Caitya 1500 Years of Buddhist Votive Architecture in the Kathmandu Valley. London: Axel Menges. 1997, p. 85. Print.

50 Ibid. P. 13. 
popularly identified as the ruin of a Kirāta Palace." ${ }^{51}$ She also tells that "the stūpas do not occupy the cardinal points of the compass, as consistently reported, nor are they equidistant from the present city center or any other point. From the Durbār square crossroads, the East stūpa is almost a mile, the North stūpa less than a half-mile, and the distance between the East and West stūpas is one and a half miles, compared to less than a mile between the North and the South ones." 52

Among them, the three stūpas are still in their original shape in earthen mounds except for Yampi stūpa. The northern mound stands at the edge of human settlement; on the banks of the river Bāgmati. Neils Gutschow states, "Until the beginning of the 20th century, the mounds differed in size but, as a common feature, were all covered by turf. Recent changes have resulted in retaining walls by way of a drum around the base, with shrines dedicated to the usual Buddhas. Even the cubes and domes with finials on top are of recent origin. With a diameter of 47.40 meters and a height of 11.80, the southern mound is the largest monument of the valley and has been exposed to beautification campaigns since the 1990s. Niches with the Buddhas were already in place at the western mound in 1455, while those at the eastern one date to 1846. An inscription tells us that on the western stūpa the Buddhas were already in place 1455." ${ }^{53}$ Mary Slusser states that "the south stūpa is much larger than its companions, with a diameter of 159 feet, which makes it considerably broader than the great stūpa of Sãnci. Reminiscent of the latter's medhi and elevated circumambulatory path, the south stūpa is erected on a circular platform. Of carefully laid brick masonry all but obscured by grass and general decay, the platform extends almost fifty feet beyond the stūpa. It is possible that, like the Maurya stūpas, this stūpa also once had an enclosing rail." ${ }^{54}$ Throughout the time, the stūpa architecture seems to have received new additions. The three stūpas - Tetā, Lagan and Phucho still seem to have an earthen mound base in which Vajrayāni architecture was added later above the stūpa. The prototype of Śvayambhūcaitya built above the earthen mound, whereas the finial was patterned of the Boudha Caitya. Although the Yampi stūpa stands in the form of a modern architecture, we can easily say its initial shape was made using an earthen mound. These stūpas are the earliest stūpas of the Kathmandu Valley. It therefore indicates that the earliest stūpas of Kathmandu valley were earthen mounds.

51 Mary Shepherd Slusser. Nepāl Mandala a Cultural Study of the Kathmandu Valley. Vol. 1. Kathmandu: Mandala Book Point. 1998. p. 279. Print.

52 Ibid. p. 278

53 Gutschow. op. cit. no. 49. p. 86.

54 Slusser. Op. cit. no. 50. p. 278. 


\section{Conclusion}

The initial stūpas were erected from earthen mounds after Buddha's Mahāparinibbāna till the time of Emperor Asoka's time in Kapilvastu. Most of the stūpas were damaged and destroyed from natural disasters. Emperor Asoka had renovated some stūpas and used bricks over the earthen mound to protect the initial stūpas. In Kapilvastu, the brick stūpas were erected during and after the Asokan period till the 3rd century CE. In Kathmandu valley, the earthen stūpas were also built during the 3 rd century BC. The initial earthen stūpas were not only reconstructed and renovated, they were often periodically enlarged and added. But the core still remained original. Thus, it can be said that the stupas constantly went through evolutionary changes in the character. Hence, the newly renovated stūpas were very likely to adorn the existing norms and practices of art and architectural styles, forms, materials and even interpretations. All this shows that the stūpas were erected according to the socioreligious, cultural and political traditions, norms and values of the country.

\section{Work cited}

Beal, Samuel. Si-yu-ki Buddhist Records of the Western World. Vol. II. Delhi: Low Price Publications. 2008.

Beal, Samuel. Travels of Fah-hian and Sung-yu AD 400 and 518 Buddhist Pilgrims from China to India, New Delhi: Asian Educational Services. 2003. Print.

Bhikkhu Pesala. 'An Exposition of The Mahāparinibbāna Sūtta, pdf.' Google. Oct. 2018. Access on 30th Nov. 2020. http://www.aimwell.org/An\%20Exposition\%20of\%20 the\%20Mahaparinibbana\%20Sūtta.pdf

Bidari, Basanta. Kapilvastu The World of Siddhartha. Lumbini: The Sacred Garden. 2007. Print.

Gutschow, Niels. The Nepālese Caitya 1500 Years of Buddhist Votive Architecture in the Kathmandu Valley. London: Axel Menges. 1997. Print.

Jataka 352. (Trans. Dunda Bahadur Vajracharya). Jataka. Lalitpur: Bir-Purna Pustak Samgrahalaya. 2011. Print.

Levi, Silvain (Trans. Dilli Raj Upreti). Nepal. Part II. Lalitpur: Hiaml Kitab. Print. Pipllayana, Madhukara. Mahan Samrat Aśoka. 5th Edition. Nai Delhi: Samyaka Prakashana. 2008, Print.

Ranjitkara, Junu Basukala. 'Essemce of Recognizing Chārumatī stūpa as World Buddhist Heritage'. International Buddhist Conference on "Promotion, Protection \& Preservation of Buddhist Culture and Heritage”. 15-18 Nov. 2014. Print. 
Ranjitkar, Junu Basukala. 'Mahotsavama matrai Chamkiyeko Birgunjsthita Visva stūpa'. Sampada Nepal. year II, no. 2, 2068 V.S. Print.

Ranjitkara, Junu Basukala. Tehis Saya Varsa Purano Eitihasika Carumati stupa. Kathmāndu: Chārumatī Buddhist Misson Nepal. 2011. Print.

Rijal, Babu Krishna. 100 years of Archaeological Research in Lumbini, Kapilvastu \& Devadaha. Kathmandu: S.K. International Publishing House. 1996. Print.

Rijal, Babu Krishna. 'Archaeological Note on the Twin stūpas in Dhamnihawa, pp. 119-125'. Nepālese Cultural Heritage in a Nutshell. Kathmandu: H.M.G. Hotel Management \& Tourism Training Centre. No Date. Print.

Sarkar, H. Studies in Early Buddhist Architecture of India. Delhi: Munshiram Monoharlal. 1966. Print.

Slusser, Mary Shepherd. Nepal Mandala a Cultural Study of the Kathmandu Valley. Vol. 1. Kathmandu: Mandala Book Point. 1998. Print.

Smith, Vincent A. 'Prefatory Note, pp. 1-22'. Antiquities of Kapilvastu Tarai of Nepal. Varansi: S.B. Singh. 1901. Print.

Wright, Daniel. History of Nepal. 3rd Edition. Calcutta: Ranjana Gupta. 1966. Print. 